\section{Memes na formação inicial de professores de inglês}

Memes in English teachers' pre-service education

Nayara Stefanie Mandarino SILVA (UFS) nayaramandarino@hotmail.com Thainná Melo NUNES (UFS) thainna506@gmail.com

Recebido em: 01 de ago. de 2020. Aceito em: 29 de set. de 2020 .
SILVA, Nayara Stefanie Mandarino; NUNES, Thainná Melo. Memes na formação inicial de professores de inglês. Entrepalavras, Fortaleza, v. 11, n. 1, e2016, p. 1-23, jan.-abr./2021. DOI: $10.22168 / 2237-6321-12016$.

Resumo: Entendendo a importância dos memes na cibercultura e considerando as potencialidades do trabalho com esse gênero textual híbrido nas aulas de língua inglesa, este artigo visa analisar atividades propostas por professores em formação inicial nas quais memes são trabalhados. A pesquisa foi desenvolvida com graduandos do curso de Letras Inglês de uma universidade federal do nordeste do Brasil. A metodologia utilizada é qualitativa e se delineia como um estudo de caso. Além disso, o referencial teórico inclui Dawkins (1976; 1986), Díaz (2013), Gee (2004) e Knobel e Lankshear (2007), entre outros. A análise das atividades/ aulas planejadas pelos participantes demonstra a pouca importância dada às imagens e a dificuldade na exploração das potencialidades dos memes, especialmente no que concerne ao trabalho adotando uma perspectiva crítica.

Palavras-chave: Memes. Formação Inicial de Professores. Língua Inglesa. 
V. $11(1)$

$1-23$

jan-abr

2021

Abstract: Understanding the importance of memes in the cyberculture and considering the potentialities of working with this textual hybrid genre in English language classes, we analyze activities in which memes are used. They were proposed by preservice teachers who are undergraduate students of English in a federal university in the Northeast of Brazil. Moreover, literature review underlying this study includes Dawkins (1976; 1986), Díaz (2013), Gee (2004) and Knobel and Lankshear (2007). The methodology adopted is qualitative and characterized as case study. Finally, we conclude that participants give little attention to images and struggle to fully explore memes and to work from a critical perspective.

Keywords: Memes. Teachers' pre-service education. English language.

\section{Para dar início à discussão}

No Brasil, 86\% da população entre 9 e 17 anos utiliza a internet. No que diz respeito a redes sociais, cerca de 20 milhões de pessoas nessa faixa etária possuem alguma conta (COMITÊ GESTOR DA INTERNET NO BRASIL, 2018). Nesse sentido, apesar da desigualdade de acesso persistir, não é possível, nas palavras de Lévy (2009, p. 11), ignorar "as implicações culturais da cibercultura em todas as suas dimensões", ou seja, a questão da exclusão não deve impedir a abordagem e discussão das formas de expressão e desdobramentos da cibercultura, especialmente nas salas de aula; pelo contrário, esses assuntos devem ser trabalhados e a desigualdade, problematizada.

No contexto da cibercultura, os memes se destacam, sendo parte dos acessos diários à internet por milhões de brasileiros. Os memes são gêneros textuais híbridos característicos da cibercultura, por meio dos quais situações do cotidiano, ideias, (re)leituras de outros textos etc. são compartilhados. Com suas grandes possibilidades de remix, (re)edição e disseminação (CALIXTO, 2018; MACIEL; TAKAKI, 2015), os memes podem ser incluídos nas salas de aula, já podendo ser encontrados em livros didáticos e provas de vestibular, como o Exame Nacional do Ensino Médio (ENEM). Nesse sentido, para que sejam trabalhados nas aulas, os memes precisam ser discutidos na formação de professores.

Neste artigo, especificamente, tratamos da formação inicial de professores de língua inglesa, enfatizando o uso de memes nas aulas de inglês e suas possibilidades. Desse modo, o objetivo deste texto é analisar atividades propostas por professores em formação inicial nas quais memes são trabalhados. Trata-se de uma pesquisa qualitativa (FERREIRA; CALVOSO; GONZALES, 2002; LAVILLE; DIONE, 1999), caracterizada como estudo de caso (YIN, 2010), cujos participantes são alunos de graduação em Letras (Português-Inglês, habilitação dupla, e Inglês, habilitação única) de uma universidade federal do Nordeste. 


\section{Definindo memes}

As primeiras menções ao termo "meme" associado à ideia de unidades culturais, como explicam Knobel e Lankshear (2007), ocorreram há mais de 80 anos. No entanto, os estudos sobre memes fazem alusão, mais frequentemente, ao conceito desenvolvido por Richard Dawkins. O autor, no seu livro The selfish gene (1976, p. 192, nossa tradução, destaque do autor), definiu meme como "uma unidade de transmissão cultural, ou uma unidade de imitação" passada de pessoa para pessoa. A imitação, nesse caso, é colocada como central, pois o sucesso do meme depende do quão semelhante ao original ele é.

Dawkins (1976), comparando memes a genes, ainda propõe que seria possível herdar características pela cultura. Essa definição foi discutida, a partir de diferentes perspectivas, por autores como Dennet (1995) e Blackmore (1999), além de ter sido repensada pelo próprio Dawkins, no livro The Blind Watchmaker (1986). Dawkins (1986) afirma que, em vez de unidades de transmissão, os memes seriam mais complexos, padrões de informação. O autor também explica que eles não são autônomos, ou seja, não se propagam sozinhos de mente para mente e, por isso, precisam de agentes de reprodução. Uma outra mudança importante proposta pelo autor está relacionada à ideia de fidelidade de imitação como condição para o sucesso do meme. Ele defende que "na medida em que são propagados, eles podem mudar. E, talvez, memes 'mutantes' possam exercer os tipos de influência que eu estou chamando aqui de "poder replicador'" (DAWKINS, 1986, p. 158, nossa tradução). Nesse sentido, o autor destaca a capacidade de mutação do meme, associando-a à ideia de evolução cultural.

Apesar das redefinições, como Knobel e Lankshear (2007) afirmam, a concepção original de Dawkins (1976) ainda é utilizada por muitos autores como base para conceituar memes. Nesse sentido, o sucesso dos memes é frequentemente relacionado a fidelidade, fecundidade e longevidade. A primeira se refere à ideia de ser replicado de maneira fiel em relação ao original. A segunda diz respeito à velocidade de replicação do meme. Sobre isso, Knobel e Lankshear (2007) afirmam que há algumas características que contribuem para a fecundidade de um meme. São elas: o humor, pois memes engraçados têm mais chances de serem compartilhados; a intertextualidade; e a justaposição, normalmente de imagens. A longevidade, terceiro aspecto, se refere ao tempo de sobrevivência, que quanto maior for, mais chances o meme tem de ser compartilhado e recriado. 
V. $11(1)$

$1-23$

jan-abr

2021

Díaz (2013) estuda alguns dos principais conceitos de meme para, então, elaborar uma definição de memes da internet, considerando teorias da comunicação.

\begin{abstract}
Um meme da internet é uma unidade de informação (ideia, conceito ou crença), que é replicada via internet (e-mail, chat, fórum, redes sociais etc.) na forma de hiperlink, vídeo, imagem ou frase. Ele pode ser passado como uma cópia exata ou pode mudar e evoluir. [...] Um meme da internet depende tanto de um transportador quanto de um contexto social em que o transportador age como um filtro e decide o que pode seguir em frente. [...] Ele pode ser interativo (como um jogo) e algumas pessoas o relacionam com criatividade. Sua mobilidade, armazenamento e alcance são baseados na web (discos rígidos, celulares, servidores, nuvens etc.). Eles podem ser manufaturados (como no caso de marketing viral) ou emergir (como um evento off-line levado ao on-line). Seu objetivo é ser conhecido o suficiente a ponto de ser replicado dentro de um grupo (DÍAZ, 2013, p. 97, nossa tradução).
\end{abstract}

Os memes, enquanto "construções híbridas entre elementos visuais e verbais" (CALIXTO, 2017, p. 189), se caracterizam como artefatos multimodais - dado que, majoritariamente, envolvem mais de um modo (imagem, áudio, texto escrito). Nesse sentido, as diferentes modalidades interagem e proporcionam a construção e a produção de sentidos de forma integrada, permitindo remixes, reconstruções e diálogos que não se limitam ao modo escrito.

Com relação à ideia de replicação, concordamos com Calixto (2018, p. 6) ao problematizar o termo, que pressupõe "que os sujeitos são passivos e meros 'hospedeiros' da cultura", quando, na verdade, o sucesso dos memes está relacionado ao protagonismo dos usuários que os (re)criam e os ressignificam. Com o advento da Web 2.0 ${ }^{1}$, também conhecida como web participativa, as pessoas passam a ter um papel mais ativo, através, por exemplo, da criação de blogs, chats, mídias sociais; todos podem ser autores. As relações produtor-consumidor foram redefinidas e a participação coletiva se tornou possível (JENKINS, 2009; SANTAELLA, 2013). É nesse contexto que os memes da internet se encontram.

Como Díaz (2013) explica em seu conceito de meme, os transportadores - aqui chamados de compartilhadores, entendendo que eles podem compartilhar memes feitos por outras pessoas ou de autoria própria, tendo um papel ativo no processo - filtram os memes,

${ }^{1}$ A web 1.0 era baseada na modalidade read-only web, na qual somente era possível acessar sites de informação e consumir o que produtores de conteúdo desenvolviam. Os poucos usuários eram, nesse sentido, como telespectadores. 
decidindo o que seguirá em frente. Nesse sentido, o conceito de espaços de afinidade, proposto por Gee (2004), pode ser relacionado ao funcionamento desse filtro. De acordo com o autor,

um espaço de afinidade é um local ou grupo de locais onde pessoas podem se afiliar a outras, baseadas, principalmente, nas atividades compartilhadas, interesses e objetivos [...]. Elas têm afinidades por um interesse ou esforço em comum (GEE, 2004, p. 67, nossa tradução).

Memes têm mais chances de sucesso nesses espaços, pois os participantes, uma vez que há afinidade de interesses e ideias, contribuem com sua circulação, permitindo que mais pessoas, dentro desses grupos, entrem em contato com eles. O compartilhamento de memes, dessa maneira, está relacionado ao que Pariser (2011) chama de filter bubbles - a personalização de resultados com base nos sites acessados pelos usuários, que acaba criando uma bolha, dado que só vemos coisas semelhantes ao que acessamos. Santaella (2018, p. 98) problematiza esse fenômeno, afirmando que

máquinas de buscas e mídias sociais promovem a segregação ideológica, pois o usuário acaba por se expor quase exclusivamente a visões unilaterais dentro do espectro político mais amplo. Quando muito arraigada devido à repetição ininterrupta do mesmo, a unilateralidade de uma visão acaba por gerar crenças fixas, amortecidas por hábitos inflexíveis de pensamento, que dão abrigo à formação de seitas cegas a tudo aquilo que está fora da bolha circundante.

Desse modo, as pessoas compartilham memes com os quais se identificam em nível ideológico, assim como, mais frequentemente, entram em contato com memes que reforçam suas crenças, o que pode causar inflexibilidade de pensamento e intolerância com diferentes formas de pensar. No entanto, ao passo que podem reforçar valores sociais, os memes também podem ser uma ferramenta para a negociação de normas, pois, ao questionar valores, podem contribuir com a formação deles (GAL; SHIFMAN; KAMPF, 2015). Considerando essas possibilidades, entendemos que a mera utilização de memes em sala de aula não garante que os alunos consigam refletir acerca da suas leituras e realidades. Assim como todas as tecnologias, se utilizadas sem um propósito e sem problematização, poderão reforçar ideologias dominantes em vez de questioná-las. O modo como os memes serão trabalhados é que define qual das possibilidades será desenvolvida. 
V. $11(1)$

$1-23$

jan-abr

2021

Os professores desempenham papel importante para guiar os alunos nos processos de (des)construção de ideias. Nesse sentido, a perspectiva do letramento ${ }^{2}$ crítico (LC) pode fundamentar o trabalho com memes nas aulas de idiomas. O LC entende a língua como espaço ideológico de construção de sentidos cuja existência se dá em práticas sociais (JORDÃO, 2013). Desse modo,

não temos acesso a uma realidade "fora do texto" (DERRIDA, 1976), uma vez que nossos entendimentos de mundo são sempre construções sociais, culturais, políticas, interpretativas. A "materialidade linguística" aqui [no LC] é conceituada em relação à concepção sócio-histórica da linguagem, ou seja, é entendida como a ideia de que a linguagem não é produto exclusivo da subjetividade individual, mas está também ancorada externamente ao indivíduo em seu contexto social, histórico, político, cultural (JORDÃO, 2013, p. 74).

Os sentidos que construímos ao entrar em contato com um meme, por exemplo, estão relacionados a nossa identidade e nossas experiências, sendo possível somente através de ideologias, ou seja, da nossa perspectiva. Por isso, é necessário focar em como o eu produz significados e tomar responsabilidade pelas nossas próprias interpretações, além de refletir sobre os motivos pelos quais nós produzimos tais significados e sobre suas origens sociais. No LC, o foco não está no que o autor quis dizer ao produzir o meme, mas no que eu entendo com ele, já que tanto o leitor quanto o escritor são construtores de sentidos. Por isso, a leitura gera dissenso, isto é, surgem diferentes interpretações, o que torna o processo conflituoso (MENEZES DE SOUZA, 2011a).

A análise, neste artigo, é feita considerando a perspectiva do LC, teoria discutida com os professores em formação inicial antes da elaboração das atividades/aulas. Logo, entendemos, em consonância com Jordão (2013, p. 81), que o conhecimento é "saber construído socialmente e sempre ideológico, incompleto, deslizante, múltiplo e relativo; é saber sempre passível de contestação, questionamento e transformação". Nesse sentido, a multiplicidade deve ser explorada

\footnotetext{
${ }^{2}$ A definição de letramento passou por mudanças ao longo do tempo. Como explica Bezerra (2017), na década de 80, o termo era entendido como sinônimo de alfabetização. No decorrer desse período, surgem estudos que trazem reflexões sobre seu significado de modo que são abordadas questões críticas e os contextos de uso de uma língua. Porém, Bezerra (2017) aponta que somente a escrita e a oralidade são incluídas na definição. Na década de 90, o letramento é compreendido de forma mais ampla, indo além da língua e incluindo diversos modos (imagens, áudios etc.). Nesse contexto, são teorizados os multiletramentos e a multimodalidade. Nos anos 2000, há uma continuidade desses estudos. No entanto, com o desenvolvimento tecnológico, surgem as discussões de letramento em contextos digitais (BEZERRA, 2017).
} 
na sala de aula, de modo que as relações de poder e a validação de determinadas leituras como legítimas devem ser problematizadas. Os professores devem contribuir com o processo de desconstrução de verdades absolutas e levar os alunos a refletirem sobre suas próprias leituras, entendendo que elas são construções sociais. Busca-se ir além de senso-comum, superá-lo, partindo de um saber "ingênuo" para um mais "rigoroso", pautado na criticidade (MENEZES DE SOUZA, 2011b).

\section{Contexto e metodologia}

A pesquisa da qual este artigo trata é qualitativa, pois visa à análise de um fenômeno em um contexto específico para compreendêlo, sem intenção de medi-lo ou de fazer generalizações (FERREIRA; CALVOSO; GONZALES, 2002; LAVILLE; DIONE, 1999). Além disso, é delineada como um estudo de caso, pois procura responder como professores de língua inglesa em formação inicial trabalham ou pensam em trabalhar com memes em suas aulas e considerando que "o pesquisador tem pouco controle sobre os eventos e [...] o foco se encontra em fenômenos contemporâneos inseridos em algum contexto da vida real" (YIN, 2010, p. 19). Os dados analisados foram coletados na plataforma Google Classroom³, usada na disciplina da graduação em Inglês, "Tecnologias no Ensino de Língua Inglesa", na qual ministramos uma oficina sobre memes, a convite da professora-formadora por ela responsável.

A disciplina foi ofertada por uma universidade federal da região Nordeste do Brasil, no ano de 2019. Ela é obrigatória para alunos do curso de Letras Inglês, cursando o quarto semestre (do total de nove). Dessa maneira, a maior parte dos alunos cursava esse período, apesar de haver discentes de semestres mais avançados cursando a disciplina como optativa. A maioria dos graduandos não atua como professor, mas alguns ensinam em cursos livres de idiomas.

A proposta da oficina envolveu a discussão do conceito de memes - com análise de alguns exemplos - e teorias relacionadas, mas não limitadas, ao ensino de línguas, como LC (MENEZES DE SOUZA, 2011a) e multiletramentos (COPE; KALANTZIS, 2009). Então, foram compartilhadas atividades em que memes eram trabalhados e

\footnotetext{
3 O Google Classroom é uma plataforma gratuita do Google, que permite a criação de turmas virtuais onde conteúdos e atividades podem ser postados tanto por professores quanto pelos próprios alunos.
} 
V. $11(1)$

$1-23$

jan-abr

2021

que lidavam com a língua inglesa a partir de diversas perspectivas4 ${ }^{4}$ O objetivo era que os professores em formação inicial as analisassem, observando se o meme era bem explorado e refletindo sobre o conceito de língua que as perpassava. No fim da oficina, os graduandos ficaram encarregados de realizar, preferencialmente em grupos, a seguinte atividade e enviar suas respostas via Google Classroom: Considerando nossas discussões, pense em uma atividade para uma aula de língua inglesa na qual você use memes. Durante o planejamento, reflita sobre as seguintes questões: Como a língua está sendo abordada? Os memes são realmente necessários na atividade? É possível realizar a mesma atividade sem o meme? Os alunos estão sendo encorajados a refletir sobre suas próprias leituras/realidades? 5

$\mathrm{Na}$ plataforma, os licenciandos deveriam comentar as propostas de outros grupos e fazer sugestões. Além disso, tanto a professora-formadora responsável pela disciplina, quanto nós, enquanto ministrantes da oficina, comentamos as publicações, com perguntas para estimular a reflexão e com feedback sobre as propostas.

No total, havia 41 estudantes da disciplina na sala virtual no Google Classroom. Sete alunos realizaram a atividade proposta; quatro individualmente e três em grupo. A atividade foi facultativa e solicitada ao final do encontro, momento em que alguns alunos haviam deixado a aula (que ocorreu durante a noite); por isso, houve pouca adesão. Destacamos que todos concordaram em participar da pesquisa, autorizando a análise de suas atividades. Para proteger suas identidades, iremos nos referir àqueles que fizeram a atividade sozinhos usando a letra $\mathrm{A}$ (de aluno) e números de 1 a 4 (por exemplo, A1); o trio será denominado G (de grupo). No tópico seguinte, analisamos e discutimos os dados.

\section{Memes nas aulas de inglês: uma análise de dados}

A prática de elaboração e desenvolvimento de atividades/aulas deve perpassar a licenciatura. Historicamente, o processo de criação de instituições para a formação de professores no Brasil resultou na

\footnotetext{
${ }^{4}$ No total, foram analisadas três atividades; uma delas lidava com a língua inglesa por uma perspectiva behaviorista, outra a partir da pedagogia crítica - esta foi contrastada com o LC na oficina - e a última pelo LC.

${ }^{5}$ A aula foi ministrada em língua inglesa e, consequentemente, a atividade também (tanto o enunciado e as perguntas para reflexão no processo de planejamento quanto as respostas dos alunos). Visando à adequação à língua usada na redação deste artigo, traduzimos, de inglês para português, todos esses dados, buscando manter fielmente o que foi dito (evitando correções gramaticais).
} 
separação entre os conteúdos da área - nesse caso, a língua inglesa - e as discussões pedagógicas (SAVIANI, 2009). Essas duas partes, no entanto, não devem ser dissociadas, uma vez que ambas são importantes para a prática docente. No Brasil, de acordo com Tozetto e Gomes (2009, p. 183),

apesar dos cursos de formação inicial, de maneira geral, afirmarem unanimemente que a construção da relação teoria e prática é objetivo a ser atingido ao longo do curso, percebese uma tendência real de enfatizar a teoria em detrimento da prática. Ou ainda, a construção de conhecimentos teóricos e práticos de forma segregada, concebendo que tais conhecimentos são coisas distintas.

Porém, é necessário investir na construção de conhecimentos práticos, enfatizando a relação entre os elementos que compõem a prática docente. Nesse sentido, a perspectiva adotada neste artigo, é de que a elaboração de atividades/aulas por parte dos professores em formação inicial fortalece sua prática e contribui para o desenvolvimento de uma perspectiva reflexiva e fundamentada na práxis.

Neste tópico, mostramos as atividades ou aulas propostas pelos professores em formação inicial, analisando como os memes são trabalhados. Primeiro, abordamos as produções individuais e, então, a grupal. Reforçamos, ainda, que os professores em formação que participaram da pesquisa eram, em sua maioria, graduandos do quarto período. Isso implica que muitos tiveram pouco contato com disciplinas pedagógicas, o que é refletido em suas propostas.

A1, em seu post, simulou uma aula e escreveu como se estivesse falando diretamente com seus alunos. Como já atua no ensino de língua inglesa, A1 pensou em uma atividade em que um livro do $9^{\circ}$ ano com o qual trabalha em uma escola é utilizado; no entanto, ele não especifica que livro é esse. Abaixo, reproduzimos a proposta de A1.

Boa tarde, turma! Hoje iremos discutir memes. Abram seus livros e leiam os quatro exemplos de memes no texto, então discutam em grupos de 5 . Usem um celular para cada grupo e postem sua visão acerca dos exemplos de memes no blog da aula. Então, vocês devem produzir um texto respondendo à questão "Com quais assuntos que estão relacionados a memes vocês lidam todos os dias?" (Atividade proposta por A1, nossa tradução).

A1 decide trabalhar com o livro didático, tecnologia usada no ensino de línguas desde 1578 (PAIVA, 2015), que apresenta exemplos de memes. Sua proposta de usar esse material demonstra sua disposição 
V. 11 (1)

1-23

jan-abr

2021

de planejar aulas utilizando o que é disponibilizado pela escola, que, por vezes, oferece poucas opções.

A aula seria iniciada com o aviso de que o assunto a ser trabalhado seria "memes". Sem atividade de warm-up, ele pediria que os alunos abrissem os livros e lessem o texto. Trata-se de uma atividade de leitura. Como afirma Paiva (2012), nós lemos para atingir objetivos, de entretenimento à necessidade de aprender a fazer algo, como uma receita. Isso significa que, para realizar o ato de ler, temos propósitos; não lemos por ler. Na sala de aula, também é necessário que haja motivos para a leitura, que deve ocorrer de forma contextualizada. A1 não propõe motivos para que os alunos realizem a leitura, tampouco contextualiza o texto.

Após a leitura, eles devem discutir o que foi lido e produzir um texto respondendo à pergunta: "Com quais assuntos que estão relacionados a memes vocês lidam todos os dias?". Percebe-se, primeiramente, que não é necessário ler o texto para responder essa questão. Além disso, ela não requer a elaboração de um texto (com orações, parágrafos), dado que é possível somente listar palavras (por exemplo, "séries, filmes e piadas"). No entanto, a pergunta elaborada por A1 mostra sua preocupação de trazer as experiências dos alunos para a aula, o que pode contribuir com o engajamento e a construção de conhecimento de forma mais significativa. A aula é finalizada com a postagem das respostas dos grupos no blog da turma.

Cabe ressaltar que A1 tenta utilizar os memes e o blog da turma na aula, se propondo a incorporar esses elementos. Provavelmente, por estar no início da graduação, o aluno-professor teve dificuldade de potencializar suas escolhas para a aula, apesar de já atuar no ensino de língua inglesa. A atividade proposta poderia explorar os memes como "artefatos sociolinguístico-culturais on-line, os quais podem ser copiados, reeditados e disseminados com propósitos sociais definidos" (MACIEL; TAKAKI, 2015, p. 54). O texto sobre memes poderia ser sobre qualquer outro assunto - sobre séries, por exemplo - e a atividade continuaria a mesma, ou seja, seria possível ler e discutir, assim como responder a mesma pergunta. Um outro recurso a ser explorado é o blog da turma, dado que os alunos apenas postam suas respostas, sendo que não há o encorajamento da escrita colaborativa, por exemplo. Como afirma Lima (2016, p. 95), o blog "é, sobretudo, a possibilidade de interação, participação, colaboração e autoria"; porém, na aula, houve dificuldade por parte do aluno-professor de explorar esses recursos. 
Isso significa que os memes e o blog foram inseridos na aula, mas as práticas de ensino continuam as mesmas que seriam sem eles. Além disso, os alunos não são encorajados a refletir sobre suas próprias leituras ou sobre questões sociais. A atividade, em resumo, incorpora o uso de celulares para acessar o blog da turma, mas a abordagem pedagógica não é repensada e os memes são apenas o assunto do texto do livro, não sendo trabalhados efetivamente.

Assim como A1, A2 elaborou a atividade individualmente. Abaixo, reproduzimos o conteúdo do seu post.

\begin{abstract}
Olá, todo mundo! Eu vou apresentar uma possibilidade de aula usando memes, minha ideia de aula começa com leituras sobre como deixar uma aula mais dinâmica e usar memes, onde os alunos iriam saber e aprender a produzir memes.

Eu iria apresentar alguns memes para eles, e usando um assunto específico da disciplina (dependendo do nível da turma), eu pediria a eles para formarem grupos e criarem memes usando um determinado tema, sendo possível usar meios tecnológicos como celulares, computadores etc. Eles poderiam fazer algo divertido e, ao mesmo tempo, envolver o tópico trabalhado na sala de aula. Os alunos teriam que analisar memes e identificar os elementos da disciplina presentes neles (Atividade proposta por A2, nossa tradução, sic).
\end{abstract}

A proposta de A2 foi vaga, dado que ela não especificou o assunto ou turma com a qual desenvolveria a atividade, o que pode ser resultado de sua pouca experiência com o planejamento de aulas. Por isso, a professora da disciplina perguntou se ela poderia compartilhar exemplos, mas não obteve resposta. A aula de A2 começaria com leituras; o texto apresentaria instruções sobre como criar um meme e abordaria como eles deixam uma aula mais dinâmica. O conhecimento acerca de como criar um meme, nesse sentido, precisaria ser passado para os alunos, no caso, através de um texto. O processo é, portanto, top-down, pois o conhecimento é "dominado" por especialistas (que ocupam uma posição hierárquica superior) que compartilham um pouco do que sabem com os que não sabem (os alunos), ou seja, o conhecimento é transmitido de cima para baixo (GEE, 2004). A2 parece entender que, para fazer os memes, os alunos devem receber instruções. No entanto, como explica Gee (2004, p. 11, nossa tradução), uma "aprendizagem profunda funciona melhor como um processo cultural do que como um processo instruído". Isso significa que é menos eficiente ler instruções sobre como fazer um meme do que aprender por ser parte da cultura dos memes. Estes, como defende Calixto (2018), são uma das principais formas de expressão na cibercultura, sendo possível encontrá-los ao 
V. $11(1)$

$1-23$

jan-abr

2021

acessar redes sociais ou ao trocar mensagens por WhatsApp. Logo, grande parte dos alunos já compartilha e interage com os memes no ciberespaço. Por que, então, tratar de forma instrucionista esses bens simbólicos que fazem parte da cibercultura na qual os alunos já estão inseridos?

Questionamos, ainda, a proposta de ensinar-a-fazer em vez do aprender-fazendo. Gee (2004) exemplifica essa situação com vídeo games; os jogadores não leem manuais de instrução antes de começar a jogar, aprende-se ao mesmo tempo em que se joga. Considerando que memes são parte das interações de muitos alunos, por que entregar um manual de instruções sobre como fazer memes? E por que não promover uma participação coletiva (JENKINS, 2009) em que os alunos, colaborativamente, ensinam e aprendem a fazer memes?

A2 ainda explica que, em sua aula, a produção de memes seria ligada a "um assunto específico da disciplina", os alunos iriam, então, analisar memes, procurando identificar esse assunto e produzir memes, de modo a incorporar o tópico trabalhado na aula. Nota-se que, apesar da tentativa de trabalhar com memes associando-os ao assunto da disciplina, o meme, por não ser explorado, é reduzido a uma maneira de trabalhar o conteúdo da disciplina. Gee (2004) denomina essa perspectiva de content fetish. A expressão se refere a definição do aprendizado em termos de conteúdo. No caso da língua inglesa, o ensino é frequentemente organizado de forma a enfatizar tópicos gramaticais. O que Gee (2004, p. 106, nossa tradução) defende é que "os domínios acadêmicos - as denominadas áreas de 'conteúdo' da escola - não são, no mundo externo, <informações>. Na verdade, eles são coisas com as quais as pessoas fazem algo". Considerando o ensino de língua inglesa, o planejamento das aulas em termos de conteúdo gramatical reforça um entendimento de língua como conjunto de informações, de regras a serem internalizadas, quando, na verdade, "a língua, que tem sua existência nas práticas sociais, é um espaço ideológico de construção e atribuição de sentidos" (JORDÃO, 2013, p. 73, ênfase da autora). Isso significa que a língua não deve ser pensada de maneira isolada das práticas sociais que a constituem e que por ela são constituídas. Dessa maneira, em vez de pensar em que conteúdo os alunos devem aprender na aula, deve-se pensar no que eles serão capazes de fazer ao experienciar a aula, ou seja, o planejamento deixa de ocorrer em função do conteúdo e passa a ser pensado em termos de práticas sociais, que são sempre permeadas por relações de poder e ideologias. Os memes, 
especificamente, enquanto produtos culturais, refletem as crenças de seus produtores, mas, ao mesmo tempo, podem funcionar como meio para questioná-las e desconstruí-las (GAL; SHIFMAN; KAMPF, 2015).

A próxima atividade, elaborada por A3, foi ainda mais vaga que a analisada anteriormente, não sendo apresentada a turma-alvo ou detalhes acerca do seu desenvolvimento, conforme veremos abaixo. Isso mostra a necessidade de, nas aulas da graduação, enfatizar a importância de considerar o contexto de ensino no momento do planejamento.

Atividade:

* Pesquise memes que representam um comentário sobre um tópico relevante.

* Compartilhe com a turma e discuta suas ideias.

* Explique como nós usamos os memes para expressar ideias e faça seu próprio meme (Atividade proposta por A3, nossa tradução, sic).

A atividade proposta por A3 parece não seguir um objetivo que, como afirma Jucá (2016), deve ser bem definido, para que o caminho para alcançá-lo possa ser estabelecido e percorrido. A3 usa instruções imprecisas e não situa a atividade em um contexto (algo acontece na aula antes da atividade? Algo acontece depois? Como exatamente essa tarefa será realizada?). Questionamos, além disso, o que seria "relevante". Seria o que o professor em formação inicial ou o que os alunos consideram importante? A ideia de permitir que os alunos decidam que tópico seria relevante para eles pode tornar a atividade mais significativa, no sentido de que haveria a oportunidade de cada um falar sobre algo que os interessa, especialmente em se tratando de memes que, de acordo com Calixto (2018, p. 5), "assim como outros produtos do ciberespaço - oferecem aos estudantes possibilidades de se expressar, mobilizar desejos e afetos, e outras experiências que, por vezes, escapam do convívio off-line". Essa proposta, porém, requer que A3 reflita sobre o que considera relevante e entenda que os alunos irão pensar diferente, ou seja, que perceba suas próprias interpretações sobre os assuntos que considera importantes e reconhecer que são leituras e não a verdade inquestionável para, dessa maneira, não acabar avaliando os tópicos escolhidos pelos alunos como certos ou errados. Como explica Jordão (2007, p. 26),

tudo o que consideramos verdade ou mentira, acerto ou erro, são sempre leituras, interpretações localizadas e construídas cultural, social, historicamente. A possibilidade ou o desejo por discursos 'verdadeiros' é considerada ilusória. 
V. $11(1)$

$1-23$

jan-abr

2021

No entanto, algumas leituras são mais legitimadas que outras, dadas as relações de poder. Na sala de aula, ao ocupar uma posição de poder, o professor corre o risco de, considerando sua leitura como a verdadeira, esperar que os alunos tenham essa mesma interpretação e entender as diferentes como erradas. Isso não significa que vale tudo; nesse sentido, o que define o que é adequado é o contexto. Por isso, é necessário que a atividade esteja situada em um contexto.

A4 aborda os memes em associação a problemas sociais. Sua proposta de atividade ocorreria após algumas discussões, as quais ela não explica detalhadamente, serem realizadas em sala de aula. Abaixo, reproduzimos o conteúdo do seu post.

\footnotetext{
Atividade usando memes:

*Trabalhem em grupos ou individualmente.

*Baseado no meme com o qual estamos trabalhando e nas discussões que tivemos na aula, pense nestas perguntas:

*Há algum problema social/político/econômico representado nele [no meme]?

Se houver, qual é/são o(s) problema(s) que o meme está abordando/humorizando?

De acordo com sua realidade, é importante compartilhar esse tipo de conteúdo? Por quê? (Atividade proposta por A4, nossa tradução, sic).
}

Aparentemente, um meme seria escolhido por A4 e os alunos iriam analisá-lo, com base em perguntas. Primeiro, com uma pergunta de sim ou não (yes or no question), verifica-se o conteúdo abordado no meme, especificamente se algum problema social/político/econômico é tratado. Em caso afirmativo, procura-se saber qual é o assunto.

Considerando os memes como unidades de imitação, seguindo a primeira definição de Dawkins (1976), Shifman (2013, p. 367, nossa tradução) propõe três dimensões que têm potencial de serem imitadas: conteúdo, forma e posição. O primeiro diz respeito a ideias e ideologias; o segundo trata da "incarnação física da mensagem, percebida através dos nossos sentidos"; e o último está relacionado ao modo como o autor posiciona a si e os que leem a mensagem. Nesse sentido, a análise de memes proposta pela aluna-professora enfatiza o conteúdo. Ainda sobre a segunda questão, $\mathrm{A} 4$ traz à tona a associação entre memes e humor, colocando que eles podem tanto abordar quanto humorizar um assunto. Na versão original, em língua inglesa, ela usa "laughing of", o que significa que esse humor tem sentido de "rir de algo". Como já foi mencionado no tópico de definição de memes, apesar de não fazer parte da definição desse gênero, o humor é importante quando se trata da 
fecundidade dos memes (KNOBEL; LANKSHEAR, 2007). Como grande parte dos memes mais compartilhados são considerados engraçados, muitas pessoas tendem a associar o gênero a humor. Ramos e Câmara (2019, p. 226) problematizam situações em que o humor é usado para propagar preconceito, como a intolerância religiosa:

Visões preconceituosas e reducionistas também são propagadas velozmente na internet por conta da facilidade em se criar e compartilhar conteúdos digitais, por isso, as ideias camufladas pelo humor que percorrem as redes sociais devem ser levadas muito a sério. Os memes cotidianamente nos chamam a atenção para disputas políticas e sociais subterrâneas, propagadas através de conteúdos encarados de forma despretensiosa, como piadas, mas que enquanto isso, no mundo real, nem sempre tem graça.

Ressaltamos a importância, nesse sentido, de problematizar o uso de memes para rir de problemas sérios que afetam pessoas. O trabalho com memes na sala de aula requer desconstrução e problematização.

Por fim, a última pergunta de $\mathrm{A}_{4}$ busca levar os alunos, considerando suas próprias realidades, a pensar sobre a importância de compartilhar "esse tipo de conteúdo". Nesse caso, há ambiguidade, pois a aluna-professora pode estar se referindo ao assunto abordado no meme ou ao meme em si. É notável, no entanto, que A4 buscou levar os alunos a estabelecer uma relação entre o conteúdo e suas próprias realidades. Essa proposta pode estimular os discentes a pensar sobre o que consideram importante compartilhar, ou seja, as ideias que decidem propagar no ciberespaço.

A última atividade foi realizada por um grupo de três pessoas. Na verdade, a proposta foi de uma aula, conforme reproduzimos abaixo:

Então, galera, hoje nós aprenderemos sobre memes! Mas, antes do conteúdo, eu quero saber o que vocês sabem sobre memes:

- O que é?

- Como podemos considerar um meme?

- Vamos falar sobre esses exemplos

Primeiro exemplo: shorturl.at/eiFKX

Segundo exemplo: shorturl.at/djwAo

Ok, depois de 'despertar' vocês, vamos criar um meme relacionado sobre qualquer assunto: social, econômico, político e assim por diante. Use a internet e um app (especialmente para criar esse tipo de projeto). Sejam criativos!

Então, postem seus memes em qualquer rede social da sua preferência: Twitter, Instagram, Facebook ou WhatsApp.

E, por último mas não menos importante, siga os comentários sobre seus memes essa rede social:

- O que os seus seguidores discutiram?

- Sobre o que eles pensaram? 
V. 11 (1)

1-23

jan-abr

2021

Discuta com seus colegas; mostre seus resultados e feedback e troque experiências com a sala de aula.

O objetivo principal dessa atividade foi começar uma discussão sobre problemas na nossa realidade. Como diferenças sociais e assuntos políticos. Encorajar a turma a ser receptiva com diferentes pontos de vista, aceitar essas diferenças e entender que é possível ter muitas leituras do mesmo meme/texto. Porque nós todos temos diferentes experiências/contextos na vida que fazem influência na maneira como vemos o mundo (Atividade proposta por G, nossa tradução, sic).

A aula proposta é iniciada com perguntas que visam descobrir o que os alunos sabem sobre memes. Então, eles devem analisar dois memes a partir de algumas questões.

Figura 1 - Primeiro exemplo de meme da aula de $G$

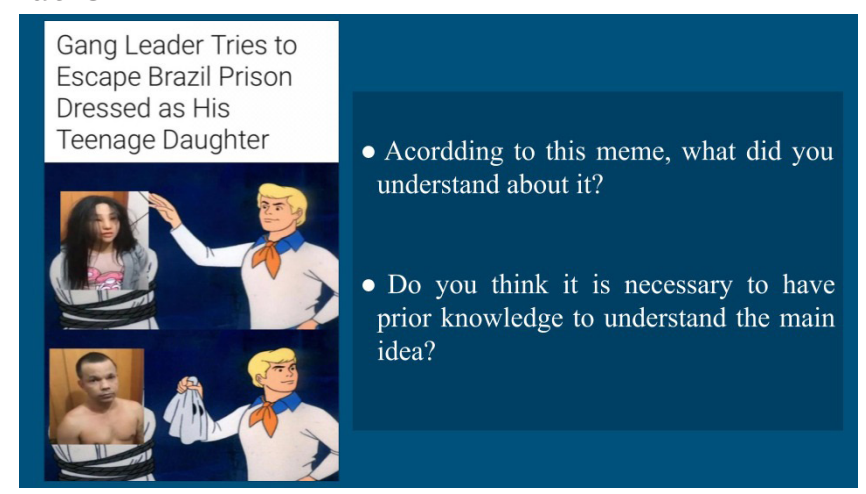

Fonte: Post de G no Google Classroom.

O meme apresentado é composto por intertextualidade (fazse referência tanto a uma notícia quanto à franquia Scooby-Doo, em que um grupo de pessoas e um cachorro investigam casos misteriosos). A primeira pergunta diz respeito ao entendimento dos alunos, de forma geral. A segunda trata da intertextualidade, requerendo somente a resposta sim, dado que é uma yes or no question. Esse tipo de questão não promove uma discussão aberta; nesse caso, uma pergunta construída com "o que", "como", "por que" (Wh questions) requer respostas mais elaboradas por parte dos alunos, além de proporcionar que eles possam se expressar mais abertamente. A intertextualidade, com essas perguntas, foi pouco explorada. 
Figura 2 - Segundo exemplo de meme da aula de G

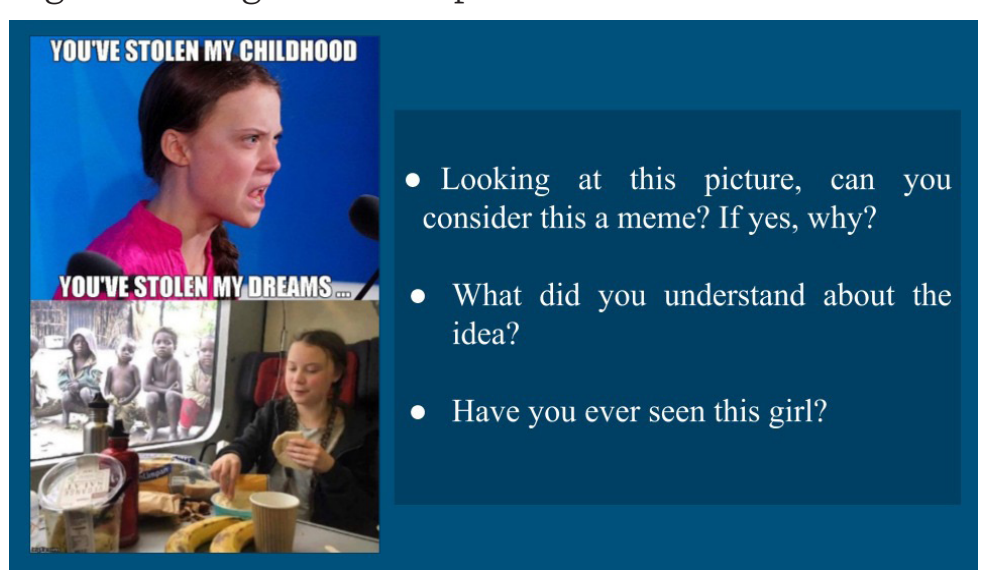

Fonte: Post de G no Google Classroom.

Novamente, G decidiu trabalhar com um meme rico em intertextualidade. Ele faz referência ao discurso proferido pela ativista ambiental Greta Thunberg na Cimeira de Ação Climática das Nações Unidas de 2019, realizada em Nova Iorque, e contrasta a realidade da garota com a de jovens negros. A primeira pergunta busca saber se e porque os alunos consideram, ou não, a imagem como um meme. Trabalham, dessa maneira, o reconhecimento das características de um meme. Além disso, assim como no exemplo anterior, perguntam o que os alunos entenderam. Por fim, com mais uma yesorno question, questionam se eles reconhecem a garota que está no meme. Essas perguntas também não exploram a intertextualidade, estabelecendo pouca relação com o discurso ao qual faz referência. Ambos os exemplos propostos por G não problematizam o conteúdo dos memes. Não há indicação, no plano, de que os memes serão discutidos mais profundamente ou de que serão feitas outras perguntas para estimular a reflexão, o que pode ser feito durante a aula, apesar de não constar na proposta.

O entendimento que parece perpassar as atividades é de que levar, para a sala de aula, memes que abordam problemas sociais e perguntar aos alunos o que eles entenderam é suficiente para "encorajar a turma a ser receptiva com diferentes pontos de vista, aceitar essas diferenças e entender que é possível ter muitas leituras do mesmo meme/texto". Porém, ao dizer o que compreenderam, cada aluno irá compartilhar sua leitura, provavelmente acreditando que ela é a verdadeira, a única forma de ler; consequentemente, as leituras diferentes seriam as erradas. A dicotomia entre certo e errado predomina não somente na escola, mas em diversos âmbitos sociais, então como, só de ouvir outras interpretações, os alunos iriam perceber 
V. $11(1)$

$1-23$

jan-abr

2021

que leituras diferentes são igualmente válidas em comparação às suas? Ao trabalhar a partir da perspectiva do LC, entendendo que tudo o que consideramos verdade são leituras e que o processo de construção de sentidos implica conflitos de interpretação (MENEZES DE SOUZA, 2011a), propõe-se que o aluno ouça a si mesmo, entendendo as implicações e as origens sociais de suas interpretações. As perguntas propostas apenas se referem ao que os alunos entenderam, não os levando a questionarem suas próprias leituras. Além disso, as questões tratadas nos memes (criminalidade, fome e pobreza, problemas ambientais) não são exploradas/problematizadas. Ao trabalhar dessa forma, corre-se o risco de reforçar as ideologias dominantes, em vez de questioná-las e desconstruí-las.

Ainda sobre a aula proposta por $\mathrm{G}$, prevê-se que os alunos criem seus próprios memes, que irão representar suas crenças com relação a algum tema, e postem em alguma rede social, esperando que outras pessoas interajam com os memes. Questionamos, mais uma vez, se o modo como essa atividade seria realizada contribuiria com o processo de levar os alunos a perceberem suas próprias leituras ou a perceberem uma diversidade de interpretações como válidas, pois: a) em suas redes sociais, muito provavelmente, eles estão inseridos em filter bubbles, ou seja, em um ambiente em que entram em contato com conteúdos e informações que reforçam suas próprias crenças (SANTAELLA, 2018); b) considerando que nossas leituras são construídas socialmente, ou seja, dentro das nossas interações e práticas sociais, é provável que, nas redes sociais, nossos contatos compartilhem de interpretações muito semelhantes às nossas e uns reforcem as ideias de outros. Silva (2019), por exemplo, analisou as (im)possibilidades do trabalho com LC através de debates, e mostrou como, muitas vezes, crenças foram reforçadas, em vez de questionadas e repensadas em momentos de debate em que a turma interpretava um assunto de forma semelhante.

Além disso, na aula de $\mathrm{G}$, assim como em todas as outras aulas/ atividades analisadas, as imagens, modo tão presente e importante para a construção de sentido em grande parte dos memes on-line, não são exploradas; são, na verdade, ignoradas do processo de interpretação, dado que não são mencionadas em momento algum pelos participantes, embora os memes sejam construções essencialmente multimodais. 
- os enunciados formados por composições visuais-verbais, cuja finalidade é a interação nas redes sociais (CALIXTO, 2018, p. 7, nosso destaque).

Como Calixto (2018) explica, as narrativas em memes são formadas por uma linguagem visual-verbal, o que significa que não é possível ler memes da mesma maneira que ocorre com textos predominantemente linguísticos; as imagens constituem o gênero, sendo essenciais para o processo de construção de sentido. Considerando a linguagem usada em ambientes digitais, Monte Mór (2008) argumenta que é necessário repensar os letramentos para incluir o trabalho pedagógico com imagens, que requerem ser lidas diferente de como vêm sendo nas abordagens mais tradicionais. Essa necessidade fica evidente com a análise das atividades/aulas propostas pelos professores em formação inicial, o que indica a importância de, na graduação, haver um trabalho com a leitura de imagens.

\section{Considerações Finais}

Os memes são gêneros textuais híbridos, considerados como uma das principais formas de expressão na cibercultura. O contato com memes é recorrente para muitas pessoas. Como explicamos anteriormente, memes são indissociáveis de práticas sociais e ideologias, que permeiam tanto sua produção quanto sua leitura, e podem reforçar ideologias dominantes e usar o humor para propagar mensagens preconceituosas que têm efeitos sociais nas vidas das pessoas. Por isso, as escolas assumem um papel importante de levar os alunos a desenvolver a prática do questionamento e desconfiança, para que, sempre que entrem em contato com memes, possam refletir sobre suas próprias leituras, além de problematizar ideologias (principalmente as que permeiam sua própria construção de sentido). Para tanto, o trabalho com memes deve ser discutido na formação de professores, de modo que eles sejam encorajados a refletir sobre as implicações de suas decisões pedagógicas na formação dos alunos.

Neste artigo, analisamos as propostas de atividades/aulas de professores em formação inicial, cursando o quarto período, procurando entender a partir de que perspectiva eles abordariam os memes. Foram, no total, cinco propostas. Apenas uma delas especificou que a atividade foi pensada para uma série específica (A1, que pensou no $9^{\circ}$ ano); os outros planos foram vagos ou pensados de uma forma geral, em uma 
V. $11(1)$

$1-23$

jan-abr

2021

perspectiva que parece refletir a ideia de que as atividades poderiam ser desenvolvidas em qualquer turma. Enfatizamos, porém, que considerar o contexto (escola pública ou particular; quem são os alunos; os materiais disponíveis etc.) em que as aulas serão desenvolvidas é crucial no processo de planejamento, ainda que, nesse caso, as propostas tenham sido pensadas de forma hipotética.

Além disso, percebemos que os professores em formação inicial não mencionaram ou trabalharam com a leitura de imagens, que compõem e são essenciais no processo de construção de sentidos de muitos memes. Isso sugere a necessidade de enfatizar a ideia de que imagens, assim como textos escritos, são espaços ideológicos de construção de sentidos; por isso, sua leitura e problematização, ainda mais no contexto da cibercultura, se tornam cada vez mais importantes.

Destacamos, ainda, que os participantes demonstraram dificuldade com relação ao planejamento de atividades/aulas, tanto no sentido de explorar as potencialidades dos memes, quanto de trabalhar segundo uma perspectiva crítica, dado que não incentivaram os alunos a refletir sobre suas próprias leituras e não problematizam as questões abordadas nos memes a serem trabalhados, o que indica a necessidade de investir em propostas como a do LC na formação desses professores. Ressaltamos que tanto essa teoria quanto a dos multiletramentos foram discutidas e analisadas em exemplos de atividade na oficina sobre memes que eles tiveram antes de elaborar as atividades. O processo de aprender como trabalhar com memes efetivamente planejando aulas, porém, com a devida discussão no próprio ambiente do Google Classroom e/ou na sala de aula presencial, pode levar esses professores a refletir sobre sua própria prática, (re)pensando as perspectivas que estão orientando suas propostas de atividades. E, por estarem cursando os primeiros períodos da graduação, eles ainda entrarão em contato, de forma mais aprofundada, com teorias e práticas de ensino e poderão rever seus entendimentos no que concerne o planejamento de aulas.

Agradecimento: Agradecemos a Ana Karina de Oliveira Nascimento por sua atenta leitura e por suas sugestões, que contribuíram com a reflexão das autoras na escrita do texto. 


\section{Referências}

BEZERRA, S. S. Letramentos em questão: um resgate histórico. Linguagem em Foco, Fortaleza, v. 9, n. 1, p. 131-139, 2017.

BLACKMORE, S. The Meme Machine. New York: Oxford University Press, 1999.

CALIXTO, D. de O. Memes na internet: entrelaçamentos entre educomunicação, cibercultura e a 'zoeira' de estudantes nas redes sociais. 2017. Dissertação (Mestrado em Ciências da Comunicação) - Escola de Comunicação e Artes, Universidade de São Paulo, São Paulo, 2017.

CALIXTO, D. Memes na internet: a "zoeira" e os novos processos constituidores de sentido entre estudantes. Revista Tecnologias na Educação, [S.l.], v. 25, n. 1, p. 1-13, 2018.

COMITÊ GESTOR DA INTERNET NO BRASIL. Pesquisa TIC KIDS ONLINE BRASIL 2018: Pesquisa Sobre o Uso da Internet por Crianças e Adolescentes no Brasil. São Paulo: GCI.br, 2018. Disponível em: https://www.cgi.br/media/ docs/publicacoes/216370220191105/tic_kids_online_2018_livro_eletronico. pdf. Acesso em: 3 jun. 2020.

COPE, B.; KALANTZIS, M. "Multiliteracies": New Literacies, New Learning. Pedagogies: An International Journal, [S.l.], p. 164-195, 2009.

DAWKINS, R. The selfish gene. London: OUP, 1976.

DAWKINS, R. The Blind Watchmaker. New York: W. W. Norton \& Company, Inc., 1986.

DENNET, D. Darwins Dangerous Idea. Great Britain: Allen Lane The Penguin Press, 1995.

DÍAZ, C. M. C. Defining and characterizing the concept of Internet Meme. Revista CES Psicología, Colombia, v. 6, n. 1, p. 82-104, 2013.

FERREIRA, R. F.; CALVOSO, G. G.; GONZALES, C. B. L. Caminhos da pesquisa e a contemporaneidade. Psicologia: Reflexão e Crítica, [S.l.], v. 15, n. 2, p. 243250, 2002.

GAL, N.; SHIFMAN, L.; KAMPF, Z. "It Gets Better": Internet memes and the construction of collective identity. New Media \& Society, [S.l.], v. 18, n. 8, jan. 2015. Disponível em: https://journals.sagepub.com/ doi/10.1177/1461444814568784. Acesso em: 10 mar. 2019.

GEE, J. Situated Language and Learning: A Critique of Traditional Schooling. New York: Routledge, 2004.

JENKINS, H. Cultura da convergência. Tradução de Susana Alexandria. São Paulo: Aleph, 2009.

JORDÃO, C. M. Abordagem comunicativa, pedagogia crítica e letramento crítico - farinhas do mesmo saco? In: ROCHA, C. H.; MACIEL, R. F. (Orgs.). Língua estrangeira e formação cidadã: por entre discursos e práticas. Campinas, SP: Pontes Editores, 2013. p. 69-90. 
V. 11 (1)

$1-23$

jan-abr

2021

JORDÃO, C. M. O que todos sabem.... ou não: letramento crítico e questionamento conceitual. Revista Crop, [S.l.], n. 12, p. 21-46, 2007.

JUCÁ, L. Ensinando Inglês na Escola Regular: a escolha dos caminhos a seguir depende de onde se quer chegar. In: JESUS, D. M.; CARBONIERI, D. (Orgs.). Práticas de multiletramentos e letramento crítico: outros sentidos para a sala de aula de línguas. Campinas: Pontes, 2016. p. 99-119.

KNOBEL, M.; LANKSHEAR, C. Online memes, affinities and cultural production. In: KNOBEL, M.; LANKSHEAR, C. (Eds.). A new literacies sampler. Berna: Peter Lang, 2007. p. 199-228.

LAVILLE, C.; DIONNE, J. A construção do saber: manual de metodologia da pesquisa em ciências humanas. Porto Alegre: Artmed, 1999.

LÉVY, P. Cibercultura. Tradução de Carlos Irineu da Costa. São Paulo: Editora 34, 2009.

LIMA, E. S. Sei navegar na internet: serei eu um letrado digital? Jundiaí, SP: Paco Editorial, 2016.

MACIEL, R. F.; TAKAKI, N. Novos letramentos pelos memes: muito além do ensino de línguas. In: JESUS, D. M.; MACIEL, R. F. (Orgs). Olhares sobre tecnologias digitais: linguagens, ensino, formação e prática docente. Campinas: Pontes, 2015. p. 53-82.

MENEZES DE SOUZA, L. M. T. O Professor de Inglês e os Letramentos no século XXI: métodos ou ética? In: JORDÃO, C. M.; MARTINEZ, J. Z; HALU, R. C. (Orgs.). Formação (Des) formatada: práticas com professores de língua inglesa. São Paulo: Pontes, 2011a. p. 279-303.

MENEZES DE SOUZA, L. M. T. Para uma redefinição de Letramento Crítico: conflito e produção de significado. In: MACIEL, R. F.; ARAÚJO, V. A. (Orgs.). Formação de professores de línguas: ampliando perspectivas. Jundiaí: Paco Editorial, 2011b. p. 128-140.

MONTE MÓR, W. Critical literacies, meaning making and new epistemological perspectives. Revista Electrónica Matices en Lenguas Extranjeras, Bogotá, $n$. 2, 2008.

PAIVA, V. L. M. Ensino de língua inglesa no Ensino Médio: teoria e prática. São Paulo: Edições SM, 2012.

PAIVA, V. L. M. de O. O uso da tecnologia no ensino de línguas estrangeiras. In: JESUS, D. M. de; MACIEL, R. F. (Orgs.). Olhares sobre tecnologias digitais: linguagens, ensino, formação e prática docente. Campinas: Ponte Editores, 2015. p. 21-34.

PARISER, E. The filter bubble: What the internet is hiding from you. London: Penguin, 2011.

RAMOS, R. R.; CÂMARA, U. F. Representação e representatividade no conflito narrativo: quando a intolerância religiosa vira meme. Revista Latinoamericana de Ciencias de la Comunicación, [S.l.], v. 16, p. 214-227, 2019. 
SANTAELLA, L. Comunicação ubíqua: repercussões na cultura e na educação. São Paulo: Paulus, 2013.

SANTAELLA, L. A pós-verdade é verdadeira ou falsa? São Paulo: Estação das Letras e Cores, 2018.

SAVIANI, D. Formação de professores: aspectos históricos e teóricos do problema no contexto brasileiro. Rev. Bras. Educ., [S.l.], v. 14, n. 40, p. 143155, 2009.

SHIFMAN, L. Memes in a Digital World: Reconciling with a Conceptual Troublemaker. Journal of Computer-Mediated Communication, [S.l.], V. 18, p. 362-377, 2013.

SILVA, N. S. M. Letramento crítico em um curso de debates do IsF-UFS: análises e possibilidades. In: V SEMINÁRIO FORMAÇÃO DE PROFESSORES E ENSINO DE LÍNGUA INGLESA, n. 8, 2019, São Cristóvão. Anais... São Cristóvão: Universidade Federal de Sergipe, 2019. p. 403-417.

TOZETTO, S. S.; GOMES, T. de S. A prática pedagógica na formação docente. Reflexão e Ação, Santa Cruz do Sul, v. 17, n. 2, p. 181-196, dez. 2009.

YIN, R. K. Estudo de caso: planejamento e métodos. Tradução de Ana Thorell. 4.ed. Porto Alegre: Bookman, 2010. 